\title{
The Interrelated Nexus of Indigenous Economic Growth and Small Business Development: Do Local Culture, Government Role, and Entrepreneurial Behavior Play the Role?
}

\author{
Yohanis Rante ${ }^{1}$ and Ari Warokka ${ }^{2}$ \\ ${ }^{1}$ Faculty of Economics - Cenderawasih University, Indonesia \\ ${ }^{2}$ Economic Development Dept., Faculty of Economics - North Sumatera University, Indonesia
}

\begin{abstract}
The rarely investigated themes on the indigenous economic's influence on small business development have made the local governments' policies on regional development merely relied on large industries as the main engine. The paper aims to examine the effects of local culture, government role, and entrepreneurial behavior on the SMEs performance. A total of 270 questionnaires was distributed to the Papuan entrepreneurs who are currently running their SMEs in the agribusiness industry, and a sample of 250 returned-questionnaires was used for further analysis. We employed the path analysis and structural equation model to investigate the relationship the determinants of indigenous economic growth and SMEs performance. The results proved that the effects of local culture and government's role were stronger and significant through the intermediating variable entrepreneurial behavior. This indirect influence revealed that selfemployed behavior was the medium to enhance and strengthen the SMEs performance. This denotes that the nexus of local culture-government role-entrepreneurial behavior plays a vital role in promoting entrepreneurship development. In addition, discussions, implications, as well as conclusions of the study were also highlighted.
\end{abstract}

Keywords: Perceived organizational support, organizational commitment, academic expatriate.

\section{Introduction}

Small businesses in Indonesia continue to play a vital role and contribute significantly in the country's economic development agenda. It had strengthened the Indonesia' economic sustainability after it could still exist and become a key driver economic growth in the post Asian Financial Crisis 1997 era. It proved prior studies that entrepreneurship drove economic innovation [and] job formation through selfemployment and small business creation (Barth, Yago, \& Zeidman, 2006). Creation and preservation of an economy that encourages entrepreneurial behavior spurs additional entrepreneurial activity. It is clear from commonly available data that small businesses are substantial employers in most areas and a source for new jobs and economic growth (Thurik \& Wennekers, 2004). Small businesses provide $75 \%$ of net new jobs (Barreto, 2006). Their cumulative economic impact makes them a force with which to be reckoned, even when individual small businesses are not considered to be major players in the economy.

Copyright (c) 2013 Yohanis Rante and Ari Warokka. This is an open access article distributed under the Creative Commons Attribution License unported 3.0, which permits unrestricted use, distribution, and reproduction in any medium, provided that original work is properly cited. Contact author: Ari Warokka Email: ari.warokka@yahoo.com 
In Papua, the special province in the mosteastern part of Indonesia and assumed as a bit less-developed region, small medium enterprises (SMEs) have been taking an increasing portion of the region economic development, especially in the coastal and lowland regencies since the last decade. Most of the businesses are agribusiness industry, which focus on farming, fisheries, and forestry-derived product's processing. Even though the Papua's SMEs growth is promising and important in the economic development, the Papuan SMEs face some various problems. Saffu (2003) in his study on the South Pacific indigenous entrepreneurship (including Papua New Guinea) reported that some constraints basically faced by the Papuan SMEs were lacked of working capital, marketing networks, qualified human capital, and technological knowledge. Meanwhile, Mansnembra (2010) in his study documented that the number of the Papuan entrepreneurs was increasing, even though not as much as non-indigenous Papuans and in terms of business size, the Papuan SMEs were relatively medium and concentrated in property and infrastructure business, which were very dependent on the government projects. He added also that the Papuan SMEs mostly operated in urban areas and felt that the capital is the main problem to expand, even though was not necessarily the case, and most of the businesses were traditionally managed. These disadvantaged could be traced to the economic system and values that came from the practice of tribal economy held by the 250 Papuan tribes for generations.

This fact is interesting since small rapidly growing firms started by entrepreneurial minded individuals, create wealth and an important number of jobs, thereby impacting greatly on social and economic development (Birch \& Medoff, 1994; Acs \& Szerb, 2007; Abubakar \& Mitra, 2010). The failure to solve the problems faced by the SMEs will bring a significant adverted impact. The Papua's province government (BPS, 2010) reported that the number of small businesses has increased averagely $2.95 \%$ in the last four years; unfortunately, it is not followed by the same rate of increasing in production, investment, and employment. Ironically, in the same period, the values of production, investment, and employment have decreased averagely $20.15 \%, 5.6 \%$, and $1.1 \%$, respectively. We predicted that the problem was related to the triple nexus of indigenous economic growth, i.e. local culture, government role, and entrepreneurial behavior.

The prior studies show that the tendency or ability to become self-employed differs between native people (indigenous) and immigrants. Immigration involves taking risks, and this is also the case for entrepreneurship. Immigrants are, therefore, considered to have an appropriate attitude or set of mind to start a business (Verheul et al, 2001). For individuals or people who are unable to adapt to a social system, such as ethnic and migrant minority groups (e.g. nonindigenous Papuans), their marginal social position is a driving force to become selfemployed. Self-employment in this case is not only a means for earning a living, but it is also a way of obtaining recognition and social acceptance (Veciana, 1999). These findings become a base for the opposite type of entrepreneurship, i.e. indigenous entrepreneurship, which is defined in terms of creating, managing, and developing new ventures by native people for the benefit of local people (Lindsay, 2005). The literatures reveal that culture influences attitudes and behavior, varies within and across nations and within and across ethnicities, and is strongly embedded in local communities (Lindsay, 2005). We assumed that the performance of Papuan SMEs was influenced by local culture, which was mediated by entrepreneurial behavior. 
The success of entrepreneurs in expanding its business, especially in the start-up stage, cannot be separated from the role of government, such as starting up permit-ease aid, access to loans, and technical assistance (Hisrich \& Peters, 1995). Those supports will encourage the local people to start new ventures and create conducive environment for entrepreneurial behavior to grow (Kao \& Liang, 2001). In the other words, the government has a major role to enhance the ability of small businesses to succeed. We assumed that the government role and local cultures simultaneously affected the Papuan SMEs' performance through entrepreneurial behavior.

This paper is intended to contribute to our understanding of the relationship between the triple nexus of indigenous economic growth and the performance of small and medium enterprises in Papua and highlight the importance of local culture, government role, and entrepreneurial behavior as the determinants to the productivity of these SMEs. Information obtained from this paper will provide a further understanding and fill the literature gap in the context of the triple nexus of indigenous economic growth's influence on entrepreneurial behavior and hence the SMEs' firm performance. Furthermore, it will examine the underlying dimensions of local culture, government role, and entrepreneurial behavior that verify the productivity. In addition, it is also considering on the local culture of entrepreneur influences the entrepreneurial behavior and lead to the productivity, how entrepreneurial behavior is being driven and executed across the many functional activities of SMEs.

To present the empirical findings, the paper is organized as follows. The literature review and prior studies on local culture, government role, and entrepreneurial behavior are briefly outlined in Section 2. In this section, the hypotheses development is also developed. The methodology and research model is described in Section3, followed by the research results and discussion in Section 4. We provide some concluding remarks in Section 5.

\section{Literature Review}

\section{The Triple Nexus of Indigenous Economic Growth}

Early economic geography researchers determined that the variation in the emergence and distribution of industry has been attributed to place-based factors, often termed regional uniqueness, including local culture (Chisholm, 1908; Hartshone, 1955). The culture of the location includes the lifestyle, values and beliefs of the area. Decisions and patterns of interaction are defined by the cultural attitudes and practices (DeBlij, Murphy \& Fouberg, 2007). This kind of interaction undeniably also affects the way of the people in its economic activities, such as trading and business activities, and SMEs activities are included. Those activities play important role as the development engine in the area. The creation of successful new ventures locally also helps to generate indigenous growth. Extant literatures reveal that small and medium enterprises (SMEs) have been the backbone of economic growth of an economy in driving industrial development. Entrepreneurship provides a basis for economic change through new knowledge creation and application but for this process to obtain value in a development context it needs a framework which can address a fairly complex set of human and social issues and enable value creation at the individual, social organizational and wider economic levels.

One of the main components of the said framework is culture. Development processes are not only associated with economic and social factors, but also correlated with culture. Culture should be incorporated as a resource to be used rather than be considered an obstacle in the process. Being aware of the local and national cultural context is of great importance in the planning and implementation of all the development cooperative efforts. Awareness 
of the local cultural context helps us understand the nature of development problems and more effectively strategies for development programs. The capacity building and empowerment of local people are also based on the understanding of the local culture. Instead of a variable dependent on economic growth, culture is seen as a controlling force that determines the development process (Lindsay, 2005).

The empirical findings show a strong correlation between entrepreneurship and economic freedom, which is promoted by government policies. Well-protected property rights, low and stable nondiscriminatory tax regimes, and few, limited regulations that are reasonable and thoughtful are the ingredients of the most successful economies. In the other words, the government could play a role in encouraging new business growth by creating an environment that is nurturing.

Those components, mediated by entrepreneurial behavior, are believed as the key drivers in the indigenous economic growth, which enable the native SMEs to flourish and perform optimally. Each component will be discussed further in the following sections.

\section{Local Culture}

Prior studies at general discussed that the various explanations of entrepreneurship can be categorized into two schools: firstly, the environment school and secondly, the people school. The first school argues that the existence of entrepreneurship is based on the cultural and structural conditions of (most often) the local environment. Some previous works of this argument's supporters, such as, the survey by Reynolds, Storey, and Westhead (1994), which focused on various economic-structural characteristics in six countries, reported the relationship between structural variables and entrepreneurship. Johannisson and Bang (1992), Davidsson (1993), and Havusela (1995) have reported this relationship, which entrepreneurship- related values and attitudes have been used as a measure indicating local culture. Meanwhile the people school argues that proactive personality (Bateman \& Crant, 1993), which is need for achievement (McClelland, 1961), locus of control (Rotter, 1966; Levenson, 1973), and tolerance of ambiguity and creativity, is the trait that determines the entrepreneurial behavior. The trait approach has found various linkages between personal characteristics and entrepreneurship.

According to Saxenian (1994) and Vandello and Cohen (1999), regional culture accounts for differences in norms, values, and practices accepted by the entrepreneurs' social network in different geographic locations. Aldrich (1999) argues that entrepreneurs who are embedded, or strongly connected to others, in a large social network are more likely to be successful when starting their business. In the other words, those who are effective in gaining high levels of accessibility to the social network can acquire resources, or social capital, that becomes available through their social relationships (Lin, 2001). Social networks, which are the proxy of local culture, are comprised of the family, friends, community members and business associates that interact with each other and other members of the network on a social and economic basis. These local cultures emerge in a specific geographic location among people with similar socio-demographic attributes (Marsden, 1988; Yamaguchi, 1990). The sharing common vision, values, beliefs, norms, ideas, trade arrangements, friendship and financial resources are the main components of this culture (Ruef, Aldrich \& Carter, 2003). Access to specific local networks allows the entrepreneur to expand his or her contacts and access to information and resources through his or her interactions with others. The ability of the entrepreneur to understand the norms and modify behavior to match the norms is necessary for entry to and continued inclusion in the local network. 
Economic development and industrial growth of a region is related to the ability of the social networks to share information, collaborate with referrals and joint projects, cost share, problem solve and share information in an open manner (Cooke, 1995; Harrison, 1994). Entrepreneurs perceive opportunity and collect information in manners influenced by their social environment (Anderson \& Miller, 2003). Prior researches also revealed that local culture through social networks that emerge around existing ventures helped potential entrepreneurs in the region gathered necessary resources for venture creation (Stuart \& Sorenson, 2003; Sorenson \& Audia, 2000). Therefore, based on those arguments, our first hypothesis is:

\section{$H_{1}$ : Papuan's local culture affects its SMEs performance}

\section{Government Role}

Local government plays a role in the ideal type public-private partnership that spurs economic development and encourages resilience in the local business community. What happens when the local government institution, through poor policy, inadequate implementation, or constraining culture, fails to help the community strive for resilience?

Classical literature on the role of government in economics suggests a range of government interaction, from a hands-off marketcentered approach of Adam Smith, to handson application of Keynesian theory that suggests the importance of government interaction in the economy to stimulate demand. Government intervenes because the market will not guarantee full employment or an equitable "distribution of wealth and incomes" (Matyas, 1994).

Local governments may also play a major role in supporting economic development initiatives. For example, the purchasing apparatus would support government's internal needs, while the economic development apparatus would support the local economy's business expansion, attraction, and retention programs, among other initiatives. The economic development program may involve incentives, entrepreneurship programs, or a publicprivate partnership, where well-established businesses work with government to encourage businesses to locate or stay in the area, or to expand their operations (Stenberg \& Austin, 2007). The goals of such programs would be to strengthen the local economy and encourage growth (Blair \& Carroll, 2008).

In Indonesia, the governments, therefore, put greater effort into strengthening the performance of SMEs by initiating many programs and incentives which based on three main strategic thrusts which aim at: (1) strengthening the enabling infrastructure, (2) building the capacity and capability of domestic SMEs and (3) enhancing access to financing by SMEs. Based on these facts, we hypothesize that:

\section{$\mathrm{H}_{2}$ : Government role affects the Papuan's SMEs performance}

\section{Entrepreneurial Behavior}

Early entrepreneurship research focused on the traits of entrepreneurs. Possession of specific traits by the individual, such as the need for high achievement (McClelland, 1961), uncertainty (Khilstrom \& Lafont, 1979), risk taking (Brockhaus, 1980b), dominance (Mescon \& Montanari, 1981), locus of control (Brockhaus, 1980a) or affiliation (Hornaday \& Bunker, 1970), are suggested as key determinants in the choice to pursue entrepreneurial venture creation. Research on traits as the distinguishing factor for entrepreneurial choice has not adequately explained the mechanism for entrepreneurship choice. 
Gartner (1988) proposed that since entrepreneurship requires implementation, it is the behaviors, not the traits that guide actions. Gartner proposed that more attention should be given to the relationship between behaviors and successful venture creation. DeCarolis and Saparito (2006) propose that it is both the environmental conditions and cognition that drive entrepreneurial behavior and opportunity exploration. Individuals tend to identify and associate with others who possess similar beliefs, values and behaviors that can assist in gaining needed resources or skills (Vandello \& Cohen, 1999). The entrepreneur learns the norms and rules of his or her social network through observation of the response to his or her actions and to the group-accepted actions of others (Bandura, 1977).

According to AmosWeb (2012), entrepreneurial behavior is a preference for changing the status quo over maintaining it based on relatively greater satisfaction generated by novel information over redundant information. It underlies the inclination to undertake invention and innovation, including the creation of something new as well as the distribution and adoption of the new throughout society. It is the behavior most likely exhibited by entrepreneurship. An alternative is managerial behavior, which is a preference for maintaining the status quo over changing it. Entrepreneurial behavior is greatly influenced by its environment.

Feldman (2001) and Julien (2007), emphasize that entrepreneurship is always a regional event, subjective and dependent on time and place because all entrepreneurs belong to a context or "milieu" at any time. Julien's (2007) "entrepreneurial milieu" is described as the "socio-economic environment surrounding the entrepreneur". A place that provides latent resources and social capital, in addition to the financial and human capital, which entrepreneurs needs to support venture creation and development. Even though Julien"s (2007) notion of the entrepreneurial milieu encompasses mostly traditional economic location factors (infrastructures, workforce, incubators etc), he also acknowledges that the milieu is a social place that promotes an entrepreneurially friendly culture, where innovative and entrepreneurial people have a chance to flourish. Thus, Julien's (2007) entrepreneurial milieu is both economic space and social place. In the other words, all components within the place where the entrepreneurs run their business play significant influence, such as culture and the support of local government.

According to the six features of an entrepreneurial ecosystem that have been identified by Babson College (Isenberg, 2011), the first two important features are the culture that rewards innovation, creativity, and experimentation and the policies and leadership that provide regulatory and capital support. The ecosystem is the prerequisite of growing entrepreneurial behavior, which consist of a set of different interconnected actors within a specific area, including the following building blocks: universities and R\&D institutions, qualified human resources, formal and informal networks, governments, angel investors and venture capitalists, professional service providers, and an enterprising culture which connects all of these factors in an open and dynamic way. It means that culture and government role determine the successful of SMEs through entrepreneurial behavior. Based on those arguments, we hypothesize that:

\section{$\mathrm{H}_{3 \mathrm{a}}$ : Papuan local culture affects its SMEs performance through entrepreneurial} behavior

\section{$H_{3 b}$ : Government role affects the Papuan's SMEs performance through entrepreneurial behavior}

\section{Small Medium Enterprise Performance}

To measure the SMEs performance is a challenging task due to the large portion of 
the extant literature is devoted to studies on how large organizations measure their performance; an apparent void of understanding how SMEs measuring their performance. Recognizing the limitations of relying solely on either the financial or nonfinancial measures, owners-managers of the modern SMEs have adopted a hybrid approach of using both the financial and nonfinancial measures. These measures serve as precursors for course of actions (Chong, 2008).

Most of prior studies on SMEs performance fall into two approaches, i.e. using the financial and non-financial measures. The financial approach (goal approach) focus their attentions on the financial measures. These measures include profits, revenues, returns on investment (ROI) (Duchesneau \& Gartner 1990; Smith, Bracker, \& Miner 1987), returns on sales (Miller, Wilson, \& Adam, 1988), and returns on equity (Richard 2000; Barney 1997) rather than the non-financial measures. Financial measures are objective, simple and easy to understand and compute, but in most cases, they suffer from being historical and are not readily available in the public domain. Inaccessibility, confidentiality (Covin \& Slevin, 1989), completeness (Sapienza \& Grimm 1997), accuracy (Brush \& Wanderwerf 1992) and timeliness (Sapienza, Smith, \& Gannon 1988) of data make comparisons among the sectors challenging and futile. Meanwhile, The most common non-financial measures adopted by the SMEs are number of employees (Orser, HogarthScott, \& Riding 2000; Mohr \& Spekman 1994; Robinson \& Sexton 1994; Loscocco \& Leicht 1993; Davidsson 1991; O'Farell 1986), growth in revenue across time (Miller, Wilson, \& Adams 1988), market share (Bouchikhi 1993; O'Farell 1986) and revenue per employee (Johannisson 1993).

In this study, we employed non-financial measures by asking the entrepreneurs to evaluate its business growth on productivity, products expansion, sales, and profitability. It was because the nature and complexity of the business structure, the Papuan entrepreneurs' knowledge level on financial literacy, and the extent of the ownersmanagers willing to participate in the fact finding processes. In addition, to measure the small firm performance, the subjective measurement is appropriate (Ahmad, 2007).

\section{Relationship between the Triple Nexus of Indigenous Economic Growth and SMEs Performance}

In the literature, the ability to leverage resources is dependent on two attributes of the social network. The first is the reach within the network to the highest level of resources. The second is related to the structure of the social network and its relationship to other social networks. Social network structures that have more structural holes and bridges create more opportunities for connection to resources. Networks that are less dense and have less strictly defined norms allow more accessibility to new entrants. Entrepreneurial success is enhanced as the entrepreneur is able to augment individual capital with social capital obtained through the social network.

Culture, as Nijkamp (2003) suggests is one of the three related factors for entrepreneurship, the other two being personal motivation and the social environment. Culture influences an entrepreneur's behavior, attitudes, and overall effectiveness and, moreover, is often unnoticed by the entrepreneur. The role of human capital in fostering entrepreneurship for development through effective resources and skills management is, therefore dependent on its ability to open up new opportunities through the use of a specific set of skills and resources in a particular cultural context. The cultural context for developing economies is inevitably different from those of their developed counterparts, and it could be argued that the same set of principles as proposed by the Washington Consensus and others may not be appropriate for such economies. Some studies have found that culture can be a dynamic factor in the economic reformation 
(Zapalska \& Edwards, 2001 in China), or that a combination of social structure and cultural values can constrain entrepreneurship (Dana (2000) in India) and that certain characteristics of local culture can be unfavorable to economic development (Cochran, 1960).

Prior studies reveal that institutions as the rules of the game in a society and organizations are the players, which institutional frameworks interact with organizations by signaling which choices are acceptable and supportable (North, 1990). Therefore, institutions help to reduce uncertainty for organizations. Mohd Shariff, Peou, and Ali (2010) point out that governments can improve opportunities available to entrepreneurs as well as strengthen the cognitive environment by offering various supports, thus, increasing the ability of entrepreneurs to conduct businesses. Following that argument, government is seen as a critical factor of business success (Hall, Daneke, \& Lenox, 2010). Government provides various means to support business activities.

Human capital is widely believed to improve entrepreneurial performance (Stuart \& Abetti 1990; Blanchflower \& Oswald 1998; Bruderl \& Preisendorfer 1998; Cooper et al. 1994; Pennings et al. 1998; Van Praag \& Cramer 2001; Van Praag 2003; Bosma et al. 2004). Following Colombo and Grilli (2005), individuals with greater human capital are likely to have better entrepreneurial judgment that leads to the successful of its business. These individuals normally behave and embrace the nature of non-resistance to change, the implementation of new ideas proposed by internal collaborators, and the incentives for accomplishing, on a continuous basis, interdisciplinary discussion and dialogue (Batjargal, 2007). Those natures are known as entrepreneurial behavior. The noneconomic performance of SMEs is positively affected by enthusiasm at work, the incentives for interdisciplinary discussion and dialogue (Leitao \& Franco, 2011). Meanwhile, the economic performance of SMEs is positively affected by enthusiasm at work, propensity for innovating activities, and capability for finding multiple solutions. As noted by Bosma et al. (2004), it is argued that the firm's performance is determined not only by the founder's talent, circumstances and good luck, but also by his individual capital, a proxy of his entrepreneurial behavior.

Based on those reviews of the literature, we proposed that local culture and government role have two types of relationship with SMEs performance, i.e. direct relationship and indirect relationship through entrepreneurial behavior as the mediating variable. Entrepreneurial behavior in this study is expected to improve the magnitude of the relationship between local culture, government role, and SMEs performance. If local culture does not support and government role is low, then entrepreneurial behavior will not support the entrepreneurs to perform optimally and enhance the SMEs performance. Baron and Kenny (1986) define the mediating variable as the mechanism through which the effect of the dependent variable can be influenced by the independent variable. The mediating variable can increase the value of the dependant variable. It measures the level of local culture effect and government role on the SMEs performance. Figure 1 show the framework of this study. 


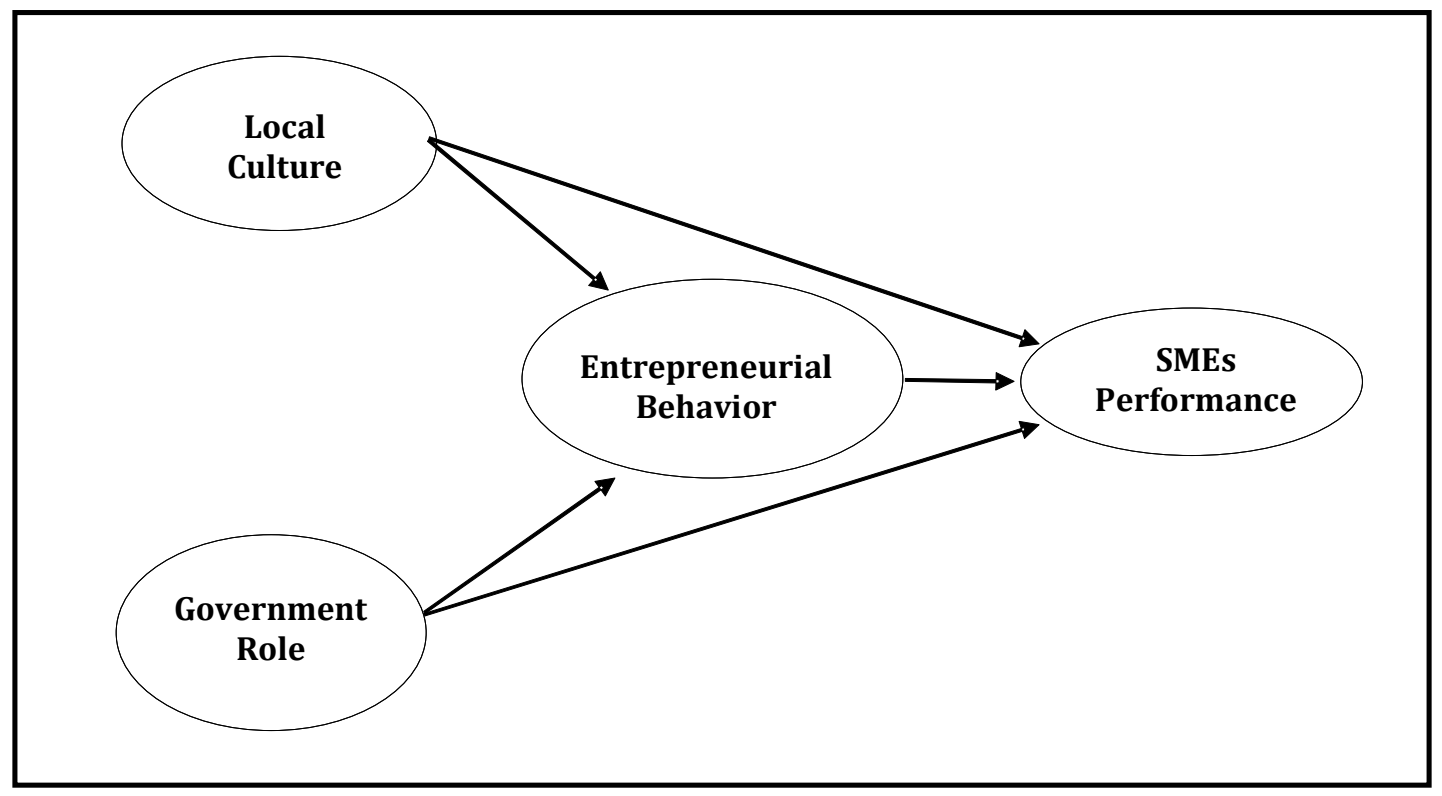

Figure 1: Research Framework on the Relationship between Local Culture, Government Role, Entrepreneurial Behavior, and SMEs Performance

\section{Research Methodology}

This study uses a mixed-method design for data collection and analysis. A survey questionnaire was employed to collect quantitative data. In-depth interviews were employed to collect qualitative data and interpret some of the survey findings. Survey and interviews are a good combination since survey questionnaires can collect data with breadth and interviews can collect in-depth, richer data. In this study, the interviews were conducted after the survey data were collected and preliminarily analyzed.

This study was conducted at three regencies in Special Province Papua (Indonesia), i.e. Merauke, Jayapura, and Keerom, and the targeted population included agribusiness small business. The agribusiness entrepreneurs were chosen for three main reasons. First, in these regions the growth of agribusiness small business had demonstrated an increasing number, compared to other regencies in Papua. Second, those regions represented two main local cultures in Papua, i.e. coastal culture and lowland culture. Third, due to its geographical position, these regencies had more infrastructure facilities and dynamic governmental activities.

\section{Samples}

The population of this study is 787 SMEs in agribusiness industry that are currently operating at three targeted regencies. The hard copy versions of the survey were distributed to the sample. From the total sample of 270 , only 255 responses were collected. Five responses were rejected due to partial responses. Therefore the final number of responses used for further analysis was 250. This signifies a response rate of $92.5 \%$.

\section{Respondents}

The 250 respondents comprised of 200 $(80 \%)$ were male entrepreneur and 50 $(20 \%)$ were the female entrepreneurs. 53 (21.2\%) respondents were Papuan entrepreneurs, and 197 respondents were non-indigenous entrepreneurs. The majority 
of the respondents were from Jayapura municipal (110 respondents or 44\%), and the rests were from Merauke regency (90 respondents or 36\%) and Keerom regency (50 respondents or 20\%). Most of the respondents were in the productive ages, i.e. $30-50$ years old $(75.6 \%$ or 198 respondents). Stock breeding and farming were the main industries in which the SMEs owners were operating their business $(70.4 \%$ or 176 respondents), and fishery was only $29.6 \%$ or 74 respondents.

\section{Measurements}

The instrument used to evaluate local culture was the compilation of work of Van de Broek (2002), Paidi (1994), Warami et al. (2007), and Rumbawer (2001) on Papuan local culture. The survey has 15 items to measure 10 dimensions of Papuan local culture. The survey requires the subjects to provide responses based on their perception of Papuan local culture on running the their business by using a five-point Likert scale from 1 denoting strongly disagree to 5 denoting strongly agree. These items were widely used in previous empirical studies with a consistent reliability result of 0.88 .

To measure the three dimension of government's role, we utilized the compiled 8 -items by Fulop (2000), Ferrel (2002), the Guidance of Rural Agribusiness Development (2008) and the Indonesian SMEs Blueprint (2009). Furthermore, the 12-items survey by Amir (2000) was employed to measure the entrepreneurial behavior. Finally, we used the non-financial 4-items by Riyanto (1998) to measure the SMEs performance. All responses were on 5-point Likert scale and ranged from (1) 'Very disagree' to (5) 'Strongly agree'.

\section{Data Analysis}

Reliability tests for the independent and dependent variables were conducted.
Subsequently, confirmatory factor analysis and structural equation model (SEM) analyses were conducted to examine the relationship between local culture, government role, entrepreneurial behavior, and SMEs performance.

\section{Results}

Table 1 shows the reliability results. The results exhibit that the reliability result were greater than 0.70 indicating reliable value for all the dimensions of the instruments. Further, the Cronbach's alpha value for local culture, government role, entrepreneurial behavior, and SMEs performance were 0.862 , $0.9060,0.9038$, and 0.8496, respectively. This demonstrates that the variables understudy have good reliability coefficient values, which are all above the lower limit of acceptability of 0.6. Meanwhile to test the construct validity, it is used three approaches of convergent validity, i.e., factor loading, composite reliability, and average variance extracted. Standardized loading estimates should be 0.5 or higher, and ideally 0.7 or higher. In this study, all valid constructs have factor loading more than 0.5. Average variance extracted (AVE) estimates for two factors also should be greater than the square of the correlation between the two factors to provide evidence of discriminant validity. AVE should be 0.5 or greater to suggest adequate convergent validity, and in this study, all valid constructs have AVE value more than 0.5. Meanwhile for composite reliability, the construct reliability should be 0.7 or higher to indicate adequate convergence or internal consistency, and in this study, all valid constructs have composite reliability value more than 0.7 . The validity and reliability test reveals that all items are reliable, which have Cronbach's Alpha value and factor loading above the minimum value 0.60 (Gujarati, 1995). Therefore, it can be said that all constructs used in this study are valid and reliable. 
Table 1: Result of CFA for Measurement Model of the Effect of Local Culture, Government Role, and Entrepreneurial Behavior on SMEs Performance

\begin{tabular}{|c|c|c|c|c|c|}
\hline & & & \multirow{2}{*}{$\begin{array}{l}\text { Factor } \\
\text { loading }\end{array}$} & \multirow{2}{*}{$\begin{array}{l}\text { Composite } \\
\text { reliability }\end{array}$} & \multirow{3}{*}{$\begin{array}{l}\text { Average } \\
\text { variance } \\
\text { extracted }\end{array}$} \\
\hline & & Internal reliability & & & \\
\hline Construct & Item & Cronbach alpha & & & \\
\hline Local Culture & Locult $_{1}$ & 0.8682 & 0.711 & 0.887 & 0.541 \\
\hline & Locult $_{2}$ & & 0.770 & & \\
\hline & Locult $_{3}$ & & 0.687 & & \\
\hline & Locult $_{4}$ & & 0.604 & & \\
\hline & Locult $_{5}$ & & 0.633 & & \\
\hline & Locult $_{6}$ & & 0.663 & & \\
\hline & Locult $_{7}$ & & 0.687 & & \\
\hline & Locult $_{8}$ & & 0.621 & & \\
\hline & Locult9 $_{9}$ & & 0.565 & & \\
\hline & Locult $_{10}$ & & 0.675 & & \\
\hline Government & Grole $_{1}$ & 0.9060 & 0.724 & 0.880 & 0.713 \\
\hline & Grole $_{2}$ & & 0.961 & & \\
\hline & Grole $_{3}$ & & 0.831 & & \\
\hline Entrepreneurial & Ebehavior $_{1}$ & 0.9038 & 0.601 & 0.906 & 0.548 \\
\hline & Ebehavior $_{2}$ & & 0.654 & & \\
\hline & Ebehavior $_{3}$ & & 0.725 & & \\
\hline & Ebehavior $_{4}$ & & 0.633 & & \\
\hline & Ebehavior $_{5}$ & & 0.684 & & \\
\hline & Ebehavior $_{6}$ & & 0.517 & & \\
\hline & Ebehavior $_{7}$ & & 0.667 & & \\
\hline & Ebehavior $_{8}$ & & 0.709 & & \\
\hline & Ebehavior $_{9}$ & & 0.590 & & \\
\hline & Ebehavior $_{10}$ & & 0.772 & & \\
\hline & Ebehavior $_{11}$ & & 0.616 & & \\
\hline & Ebehavior $_{12}$ & & 0.674 & & \\
\hline SMEs & SMEperf $_{1}$ & 0.8496 & 0.739 & 0.850 & 0.587 \\
\hline & SMEperf $_{2}$ & & 0.778 & & \\
\hline & SMEperf $_{3}$ & & 0.778 & & \\
\hline & SMEperf $_{4}$ & & 0.768 & & \\
\hline & & & & & \\
\hline
\end{tabular}

Table 2 shows the fit indices for measurement model. The indices reveal that the study's values meet the recommended values set by the prior studies. The values of GFI, AGFI, CFI, and TLI were more than the minimum value. Meanwhile, the values of $\chi^{2} / \mathrm{df}$ and RMSEA were also less than the maximum value as allowed. It means that our model has functioned well to fulfill the objective of the study. It could be continued to the next process, i.e. measure the effect of studied variables by running the path analysis and hypothesis testing. 
Table 2: Fit Indices for the Measurement Model of the Effect of Local Culture, Government Role, and Entrepreneurial Behavior on SMEs Performance

\begin{tabular}{|l|c|c|l|}
\hline Fit Index & This Study & Recommended values & Source \\
\hline $\mathrm{df}$ & 2 & & \\
\hline$\chi^{2}$ & 1.044 & & \\
\hline$\chi^{2} / \mathrm{df}$ & 0.522 & $\leq 3.00$ & Gefen, Straub, \& Boudreau (2000) \\
\hline GFI & 0.934 & $\geq 0.90$ & Hoyle (1995) \\
\hline AGFI & 0.886 & $\geq 0.80$ & Chau \& Hu (2001) \\
\hline CFI & 0.997 & $\geq 0.90$ & Bagozzi \& Yi (1988) \\
\hline RMSEA & 0.013 & $\leq 0.08$ & Browne and Cudeck (1993) \\
\hline NNFI (TLI) & 0.995 & $\geq 0.90$ & Bagozzi \& Yi (1988) \\
\hline
\end{tabular}

The measurement model indices reveal that the proposed model is fit and parsimony.

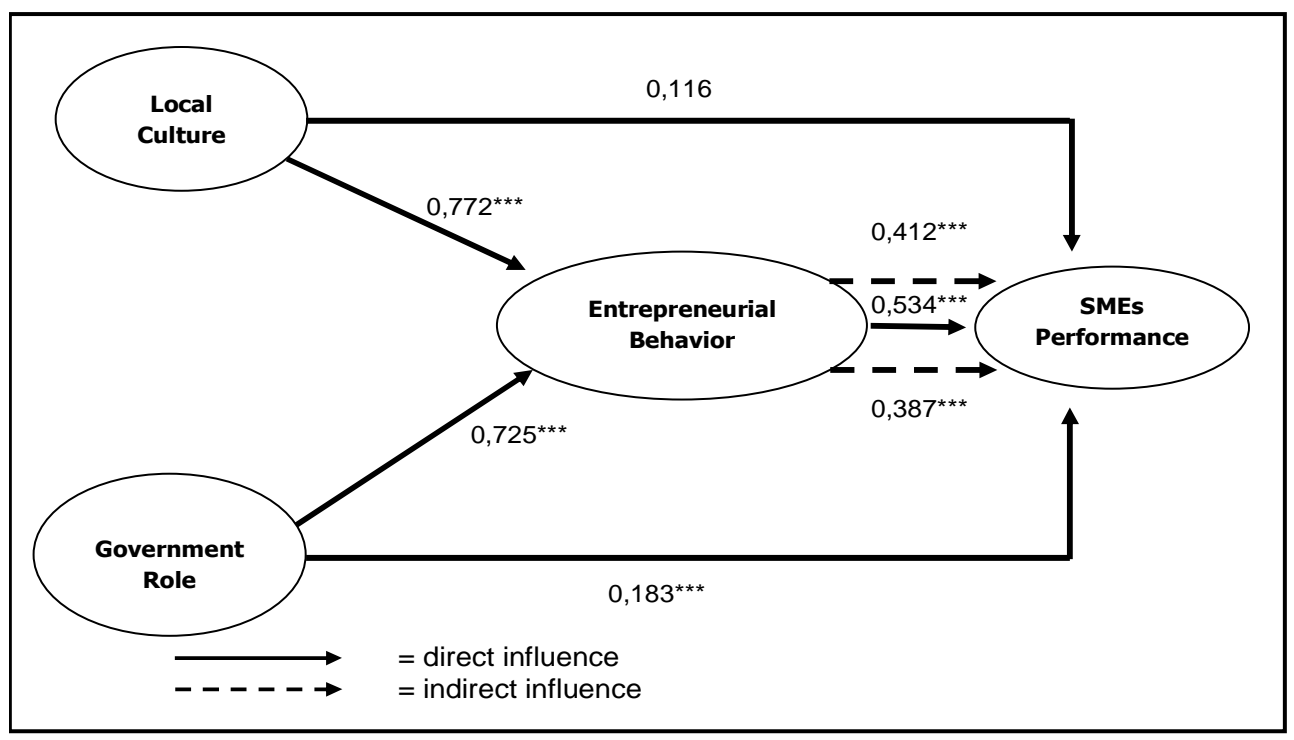

Note: ${ }^{* * *} \mathrm{p}<0.01 ;{ }^{* *} \mathrm{p}<0.05$

Figure 2: Path Coefficients and Hypothesis Testing of the Effect of Local Culture, Government Role, and Entrepreneurial Behavior on SMEs Performance

\section{Discussions and Implications}

The path and regression analysis on the direct effect of local culture on the SMEs performance demonstrated that it did not have significant influence, which the path coefficient was only 0.116 with p-value 0.256. It means that the Papuan indigenous culture does not directly influence the Papuan's small businesses' performance. According to Tebay (2007), the native Papuans have a different value system and work ethic from the prevailing laboring system in the modern enterprise. They do the works to achieve something that is obvious, i.e. the works are carried out just to meet the 
basic or necessary needs, not are specified in the certain working hours. The labor activity is also considered as a process and communal events, so that any work done should bring the social benefits to the community. The Papuans' work ethic emphasizes the collectivism, the obligation to tradition, and the less-oriented economic motives. It is lacked to support the individual's productivity and profitability, resulting in the situation in which a managed business cannot thrive. During the run the businesses, such as farming, livestock breeding, and fisheries, the Papuans always think that they have a great responsibility for the family and put the benefits of big family as the main priority. If the entrepreneurs choose to ignore the tradition obligations, they will face some risks, such as social exclusion and loss control over the access of local employment and other community resources, thus it will limit their business' progress.

However, the Papuan's indigenous culture influence on the SMEs performance through entrepreneurial behavior as the mediating variable was significant, i.e. the path coefficient was 0.412 with p-value 0.001 . The results indicate that the intermediate variable has a strategic role in linking the local culture to the SMEs performance. The Papuan's work ethic is considered as the main part of their attitudes toward economy activities, even though, the indigenous entrepreneurial behavior is more concentrated on meeting the social needs rather than the economy one.

Our study found that the government's role influenced the SMEs performance directly and indirectly. The path coefficients demonstrated that it had significant influence, which the values were 0.183 (pvalue 0.001 ) and 0.387 (p-value 0.000), respectively. Meanwhile, the entrepreneurial behavior itself had a significant influence on the SMEs performance, which was indicated with path coefficient 0.534 (p-value 0.001 ). Our study noticed that one of the main Papuan self-employed behavior indicators, which is assumed having significant influence on the business performance, is the hardworking character. Having realized that they have abundant natural resources for doing business, even though they are facing some obstacles related to the advanced business knowledge, to behave industrious are the perceived work ethic and attitude to carry out the activities enthusiastically. It becomes also a devotion to the traditional values of collectivism.

In concordance with the supportive entrepreneurial behavior on business performance, according to Chowdhury (2007), the political stability, law enforcement, improvement of infrastructure, corruption eradication, and economic assistance provided, will foster a positive climate for business development. The government assistance to small businesses through the improvement and development of infrastructure, education and training, and financial assistance is the basic condition to flourish on the conducive-entrepreneurship environment.

In the other words, the role of government is to help and support an entrepreneurial ecosystem. It implies that government should remove legal obstacles to business growth, and implement helpful laws that decriminalize bankruptcy, simplifies tax, and allows entrepreneurs to quickly start over after a failed venture. It means that the government's role is to unleash - not harness - people's entrepreneurial energies, and build on and reinforce existing clusters instead of trying to create new ones. It's a case of putting the correct systems in place and then letting entrepreneurs get on with the task at hand.

Local governments can reinforce the positive externality by keeping a close watch on emerging technologies and facilitating the emergence of early communities around promising new technologies. This may be achieved primarily through the providing information on regulations (standards, taxation, and customs duties), the 
establishment of mentoring programs, and the organization of networking events. The other supporting efforts are to create incubator units providing the space and infrastructure for business beginners and innovative companies, and the creation of media outlets where outcomes of small businesses can be publicized, and help them to solve technological problems, and to search for know-how and promote innovation.

There are no doubts that governments should create different types of support institutions, such as:

a. To provide information on regulations, standards, taxation, customs duties, marketing issues;

b. To advise on business planning, marketing and accountancy, quality control and assurance;

c. To create incubator units providing the space and infrastructure for business beginners and innovative companies, and helping them to solve technological problems, and to search for know-how and promote innovation; and

d. To help in looking for partners.

Those supports, combined with proper local culture development, will be the prerequisite for the flourished entrepreneurial behavior leading to the increasing SMEs performance.

\section{Conclusion}

This study has successfully answered the objective, which is to examine the effect of local culture, government role, and entrepreneurial behavior on SMEs performance. From the path analysis results, it was found that Papuan indigenous culture had a strong indirectly influence through self-employed behavior in the business performance. Meanwhile, the government's role had this effect significantly in both ways, direct and indirect. This finding has provided a clear path to explore more the relationship between these variables. It is important to enhance and improve managerial effectiveness of small business in Papua. Hence, at the micro level, there is a need to improve constantly the existing human resource's entrepreneurship development. It is particularly in enhancing proper local culture and supportive regional government's interventions. The results from the study have also given some inputs to the institutional decision makers in designing more favorable policies and procedures that can help improve SMEs management in the less-developed regions.

\section{References}

Abubakar, Y. A. \& Mitra, J. (2010). "Factors Influencing Innovation Performance in European Regions: Comparing Manufacturing and Services ICT Sub-Sectors," International Journal of Entrepreneurship and Innovation Management, 11(2), 156 - 77.

Acs, Z. J. \& Szerb, L. (2007). "Entrepreneurship, Economic Growth and Public Policy," Small Business Economics, 28(2/3), 109-121.

Ahmad, N. H. (2007). “A Cross Cultural Study of Entrepreneurial Competencies and Entrepreneurial Success in SMEs in Australia and Malaysia," PhD Dissertation.The University of Adelaide, Australia.

Aldrich, H. E. (1999). Organizations Evolving, London: Sage.

Amir, H. S. (2000). 'Wiraswasta Manusia Unggul Berbudi Luhur,' Jakarta.

AmosWEB Encyclonomic WEB*pedia. http://www.AmosWEB.com, AmosWEB LLC, 2000-2012. [Accessed: June 14, 2012].

Anderson, A. R. \& Miller, C. J. (2003). "Class Matters: Human and Social Capital in the Entrepreneurial Process," Journal of SocioEconomics, 32(1), 17-36. 
Bagozzi, R. P. \& Yi, Y. (1988). "On the Evaluation of Structural Equation Models," Journal of the Academy of Marketing Science, 16 (Spring), 74-94.

Bandura, A. (1977). "Self Efficacy: Toward a Unifying Theory of Behavioral Change," Psychological Review 84: 191-215.

Barney, J. B. (1997). Gaining and Sustaining Competitive Advantage, New York: AddisonWesley.

Barreto, H. V. (2006). "Introduction. In Entrepreneurship and Small Business," Retrieved March 15, 2011, from http://www.america.gov/media/pdf/ejs/01 06.pdf.

Barth, J. R., Yago, G. \& Zeidman, B. (2006). "Stumbling Blocks to Entrepreneurship in Low-and Moderate-Income Communities," In G. Yago, Barth, J. R., \& Zeidman, B. (Eds.)., Entrepreneurship in emerging domestic markets. New York: Springer.

Bateman, T. S. \& Crant, J. M. (1993). "The Proactive Component of Organizational Behaviour: A Measure and Correlates," Journal of Organizational Behavior, 14, 103 118.

Batjargal, B. (2007). "Internet Entrepreneurship: Social Capital, Human Capital, and Performance of Internet Ventures in China," Res. Pol., 36, 605-618.

Birch, D. L. \& Medoff, J. (1994). 'Gazelles,' in Solmon, L.C. and Levenson, A.R. (Eds), Labor, Markets, Employment Policy, and Job Creation, Westview Press, Boulder, CO.

Blanchflower, D. \& Oswald, A. J. (1998). "What Makes an Entrepreneur?," Journal of Labor Economics, 16(1): 26-60.

Bosma, N., Van Praag, M., Thurik, T. \& De Wit, G. (2004). "The Value of Human and Social Capital Investments for the Business Performance of Startups," Small Bus. Econ., 23: 227-236.
Brockhaus, R. H. (1980). "Risk Taking Propensity of Entrepreneurs," Academy of Management Journal. 23(3), 509-520.

Browne, M. W. \& Cudeck, R. (1993). Alternative Ways of Assessing Model Fit, In: Bollen, K. A. \& Long, J. S. (Eds.) Testing Structural Equation Models. pp. 136-162. Beverly Hills, CA: Sage

Bruderl, J. \& Preisendorfer, P. (1998). "Network Support and Success of Newly Founded Businesses," Small Business Economics, 10, 213-225.

Carroll, M. C. \& Blair, J. P. (2008). 'Local Economic Development: Analysis, Practices, and Globalization,' Los Angeles: Sage.

Chau, P. Y. K. \& Hu, P. J. H. (2001). "Information Technology Acceptance by Individual Professionals: A Model Comparison Approach," Decision Sciences, 32(4), 699-719.

Chisholm, G. G. (1908). "The Meaning and Scope of Geography," The Scottish Geographic Magazine, 24, 561 - 575.

Chong, H. G. (2008). 'Measuring Performance of Small-and-Medium Sized Enterprises: The Grounded Theory Approach,' Journal of Business and Public Affairs, 2(10), 1-10.

Chowdhury, M. S. (2007). "Overcoming Entrepreneurship Development Constraints: The Case of Bangladesh," Journal of Enterpresing Communities: People and Places in the Global Economy, 1(3), 240-251.

Cochran, T. C. (1960). "Cultural Factors in Economic Growth," The Journal of Economic History, 20(4), 515-530.

Colombo, M. G. \& Grilli, L. (2005). “Founders' Human Capital and the Growth of New Technology-Based Firms: A CompetenceBased View," Res. Pol., 34, 795-816.

Cooke, P. (1995). 'The Rise of the Rust Belt,' London: IUCL Press. 
Cooper, A. C., Gimeno-Gascon, F. J. \& Woo, C. Y. (1994). "Initial Human and financial capital as predictors of New Venture Performance," Journal of Business Venture, 9, 371-395.

Covin, J. G. \& Slevin, D. P. (1989). "Strategic Management of Small Firms in Hostile and Benign Environments," Strategic Management Journal, 10, 75-87.

Dana, L. P. (2000). 'Creating Entrepreneurs in India,' Journal of Small Business Management, 38(1), 86-92.

Dana, L. P. (2001). "The Education and Training of Entrepreneurs in Asia," Education+Training 42(8/9), 405-415.

Davidsson, P. (1991). "Continued Entrepreneurship: Ability, Need and Opportunity as Determinants of Small Firm Growth," Journal of Business Venturing, 6, 405-429

Davidsson, P. (1993). 'Kultur Och Entreprendrskap,' NUTEK, Stockholm.

DeBlij, H. J., Murphy, A. S. \& Fouberg, E. H. (2007). 'Human Geography: People Places and Culture,' Hoboken NJ: John Wiley and Sons.

De Carolis, D. M. \& Saparito, P. (2006). "Social Capital, Cognition, and Entrepreneurial Opportunities: A Theoretical Framework," Entrepreneurship Theory and Practice, 30, 4156

Feldman, M. P. (2001). "The Entrepreneurial Event Revisited: An Examination of New Firm Formation in the Regional Context," Industrial and Corporate Change, 10, 861891.

Fulop, L. (2000). "A Study of GovernmentFunded-Small Business Networks in Australia," Journal of Small Business Management, 5(3), 87-91.
Gartner, W. B. (1988). "Who is an Entrepreneur? Is the Wrong Question," American Journal of Small Business, 12(4), 1132.

Gefen, D., Straub, D. W. \& Boudreau, M. C. (2000). "Structural Equation Modeling and Regression: Guidelines for Research Practice," Communication of the Association for Information System, 4(7), 1-79.

Guidance of Rural Agribusiness Development (2008). Ministry of Agriculture Republic of Indonesia, Jakarta.

Gujarati, D. N. (1995). 'Basic Econometrics,' New York: McGraw-Hill.

Hall, J. K., Daneke, G. A. \& Lenox, M. J. (2010). "Sustainable Development and Entrepreneurship: Past Contributions and Future Directions," Journal of Business Venturing, 25(5), 439-448.

Harrison, B. (1994). 'Industrial Districts: Old Wine in New Bottles?', Regional Studies, 26, 468-483.

Hartshone, R. (1955). "Exceptionalism in Geography," American Geographer, 45, 205 244.

Havusela, R. (1995). 'Ympdristdn Rakenne ja Yrittdjyys Oulun ja Vaasan Iddneissa,' Vaasan yliopiston julkaisuja. Tutkimuksia 209. Lic.diss. Vaasa. In Finnish.

Hisrich, R. D., \& Peters, M. (1995). 'Entrepreurship,' 3th Ed., New York: Irwin/Mc Graw Hill.

Hornaday, J. A. \& Bunker, C. S. (1970). "The Nature of the Entrepreneur," Personal Psychology, 23, 47-54.

Hoyle, R. H. (1995). Structural Equation Modeling, Thousand Oaks, CA: SAGE Publications, Inc. 
Isenberg, D. (2011). "The Entrepreneurship Ecosystem Strategy as a New Paradigm for Economic Policy: Principles for Cultivating Entrepreneurship," Presentation at the Institute of International and European Affairs, May 12, 2011, Dublin Ireland. Available on line at http://entrepreneurialrevolution.com/ [Accessed: June 16, 2012].

Johannisson, B. (1993). 'Designing Supportive Contexts for Emerging Enterprises,' in C. Karlsson, B. Johannisson, \& D. Storey (Eds.), Small Business Dynamics: International, National and Regional Perspectives, London: Routledge.

Johannisson, B. \& Bång, H. (1992). 'Nyföretagande och Regioner, Modeller, Fakta, Stimulantia,' Arbetsmarknadsdepartmentet, Stockholm.

Julien, P. A. (2007). A Theory of Local Entrepreneurship in the Knowledge Economy, Northampton, MA: Edward Elgar Publishing.

Kao, R. W. \& Wee, L. T. (2001). 'Entepreneurship and Enterprise Development,' Singapore: Pearson Education Asia Pte Ltd.

Kihlstrom, R. E. \& Laffont, J.- J. (1979). “A General Equilibrium Entrepreneurial Theory of Firm Formation Based on Risk Aversion," Journal of Political Economy, 87(4), 719-748.

Leitão, J. \& Franco, M. (2011). "Individual Entrepreneurship Capacity and Small and Medium Enterprises (SME) Performance: A Human and Organizational Capital Approach," African Journal of Business Management, 5(15), 6350-6365.

Levenson, H. (1973). "Activism and Powerful Others: Distinctions with the Concept of Internal - External Control," Journal of Personality Assesment 38, 377 - 383.

Lindsay, J. N. (2005). "Toward a Cultural Model of Indigenous Entrepreneurial Attitude," Academy of Marketing Science
Review, Vol. 2005 No. 05 Available: http://www.amsreview.org/ articles/lindsay05-2005.pdf Copyright (C) 2005 - Academy of Marketing Science.

Lin, N. (2001). Social Capital: A Theory Of Social Structure and Action, New York: Cambridge University Press.

Loscocco, K. A. \& Leicht, K. T. (1993). "Gender, Work-Family Linkages and Economic among Small Business Owners," Journal of Marriage and the Family, 5, 875887.

Mansnembra, C. (2010). 'Inisiasi Terobosan Baru Untuk Penguatan Pengusaha Asli Papua (Creative Breakthrough to Enhance the Indigenous Papuan entrepreneurs),' Presented in a one-day seminar "Building Papuan Entrepreneurs”, August 27, Jayapura.

Marsden, P. V. (1988). "Homogenity in Confiding Relationship," Social Networks, 10, 57-76.

Matyas, A. (1994). 'Similarities between the Economic Theories of Marx and Keynes,' In J.C. Wood (Ed.). John Maynard Keynes: Critical Assessments, Volume 5. London: Routledge.

McClelland, D. (1961). 'The Achieving Society,' Princeton: New Jersey. Van Nostrand.

Mescon, T. S. \& Montanari, J. R. (1981). 'The Personalities of Independent and Franchised Entrepreneurs,' Academy of Management Proceedings, 413-317.

Miller, A., Willson, B. \& Adams, M. (1988). "Financial Performance Patterns of New Corporate Ventures: An Alternative to Traditional Measures," Journal of Business Venturing, 3(4), 287-299.

Mohd Shariff, M. N., Peou, C. \& Ali, J. (2010). "Moderating Effect of Government Policy on Entrepreneurship and Growth Performance 
of Small-Medium Enterprises in Cambodia," International Journal of Business \& Management Science, 3(1), 57-72.

Mohr, J. \& Spekman, R. (1994). "Characteristics of Partnership Success: Partnership Attributes, Communication Behavior, and Conflict-Resolution Techniques," Strategic Management Journal, $15,135-152$.

Nijkamp, P. (2003). "Entrepreneurship in a Modern Network Economy," Regional Studies, 37(4): 395-405.

North, D. C. (1990). Institutions, Institutional Change and Economic Performance, Cambridge: Cambridge University Press.

O'Farell, P. \& Keeble, D. (1986). 'The Nature of New Firms in Ireland: Empirical Evidence and Policy Implications,' in D. Keele, and E. Wever (Eds.) New Firms and Regional Development in Europe. London: Croom Helm, 151-183.

Orser, B. J., Hogarth-Scott, S. \& Riding, A. L. (2000). "Performance, Firm Size and Management Problem Solving," Journal of Small Business Management, 38(4), 42-58.

Paidi, Y. (1994). 'Pentingnya Nilai Sosial Budaya Cerita Rakyat Waropen Terhadap Pembangunan di Kabupaten Yapen Waropen Irian Jaya,' Penelitian FKIP UNCEN. Jayapura.

Pennings, J. M., Lee, K. \& Van Witteloostuijn, A. (1998). "Human Capital, Social Capital, and Firm Dissolution," Academy Management Journal, 41(4), 425-440.

Reynolds, P. D., Storey, D. \& Westhead, P. (1994). 'Regional Characteristics Affecting Entrepreneurship: A Cross National Comparison,' In Frontiers of Entrepreneurship Research. Babson Park, MA: Babson College

Richard, O. C. (2000). '"Racial Diversity, Business Strategy and Firm Performance: A
Resource Based View," Academy of Management Journal, 43(2), 164-177.

Robinson, P. B. \& Sexton, E. A. (1994). "The Effect of Education and Experience on SelfEmployment Success," Journal of Business Venturing, 9(2), 141-156.

Rotter, J. B. (1966). Generalised Expectancies for Internal Versus External Control of Reinforcement,' Psychological Monographs Whole, 609, 80.

Ruef, M., Aldrich, H. E. \& Carter, N. M. (2003). "The Structure of Founding Teams: Homophily, Strong Ties and Isolation among US Entrepreneurs," American Sociological Review, 68, 195 - 222.

Rumbrawer, F. (2001). 'Warta UNCEN, Edisi X Maret 2011,' Jayapura.

Saffu, K. (2003). "The Role and Impact of Culture on South Pacific Island Entrepreneurs," International Journal of Entrepreneurial Behaviour and Research, 9(2), 55-73.

Sapienza, H. J. \& Grimm, C. M. (1997). 'Founder Characteristics, Start-Up Process and Strategy/Structure Variables as Predictors of Shortline Railroad Performance,' Entrepreneurship Theory and Practice, 22(1), 5-22.

Sapienza, H. J., Smith, K. G. \& Gannon, M. J. (1988). 'Using Subjective Evaluations of Organizational Performance in Small Business Research,' American Journal of Small Business, 12(3), 45-53.

Saxenian, A. L. (1994). Regional Advantage: Culture and Competition in Silicon Valley and Route 128, Cambridge, MA: Harvard University Press.

Smith, N. R., Bracker, J. S. \& Miner, J. B. (1987). 'Correlates of Firms and Entrepreneur Success in Technologically Innovative Companies,' in N. C. Churchill 
19 Journal of Innovation Management in Small \& Medium Enterprises

(Ed.) Frontiers of entrepreneurship research, Wesley, MA: Babson College Press, 57-71.

Sorenson, 0. \& Audia, P. G. (2000). "The Social Structure of Entrepreneurial Activity: Geographic Concentration of Footwear Production in the United States," 1940-1989. American Journal of Sociology, 106, 424-462.

Stenberg, C. W. \& Austin, S. L. (2007). Managing Local Government Services: A Practical Guide, Washington, D. C.: ICMA

Stuart, R. W. \& Abetti, P. A. (1990). "Impact of Entrepreneurial and Management Experience on Early Performance," Journal of Business Venture, 5, 151-162.

Stuart, T. \& Sorenson, O. (2003). "The Geography of Opportunity: Spatial Heterogeneity in Founding Rates and the Performance of Biotechnology Firms," Research Policy, 32(2), 229-53.

Tebay, N. (2007). 'Dampak Masuknya Perusahaan Perkebunan Terhadap Kesejahteraan Masyarakat Asli Papua (The Impact of Plantation Firms on the Indigenous Papuans' Welfare),' paper presented in the national workshop on entrepreneurship, Sekolah Tinggi Filsafat Teologi (STFT) Fajar Timur, Jayapura, 21 March 2007.

Thurik, R. \& Wennekers, S. (2004). "Entrepreneurship, Small Business and Economic Growth," Journal of Small Business and Enterprise Development, 11(1), 140 - 9.

Vandello, J. A. \& Cohen, D. (1999). "Patterns of Individualism and Collectivism across the US," Journal of Personality \& Social Psychology, 77(2), 279-292.

Van Den Broek, T. P. A. (2002). 'Mengatasi Keterpecahan Yang Melumpuhkan,' Diterbitkan atas kerjasama Sekretariat Keadilan dan Perdamaian Keuskupan
Jayapura dan Lembaga Studi Pers dan Pembangunan. Jayapura - Indonesia.

Van Praag, C. M. (2003). "Business Survival and Success of Young Small Business Owners: An Empirical Analysis," Small Business Economics, 21(1), 1-17.

Van Praag, C. M. \& Cramer, J. S. (2001). "The Roots of Entrepreneurship and Labor Demand: Individual Ability and Low Risk Aversion," Economica, 269, 45-62.

Veciana, J. M. (1999). 'Entrepreneurship as a Scientific Research Programme,' Revista Europea de direccion y Economia de la Empressa, 8(3), 21-33.

Verheul, I., Risseeuw, P. \& Bartelse, G. (2001). 'Gender Differences in Strategy and Human Resource Management,' Rotterdam Institute for Business Economic Studies 2001/3.

Verheul, I. \& Thurik, T. (2001). "Start-Up Capital: Does Gender Matter?," Small Business Economics, 16, 329-345.

Verheul, I., Wennekers, S., Audretsch, D. \& Thurik, R. (2001). 'An Eclectic Theory of Entrepreneurship: Policies, Institutions and Culture,' Research Report 0012, EIM, Zoetermeer.

Warami, H., Wamafma, N., Hieronimus, J., Waramori, S., Tulalessy, Q., Sonbait, L. \& Muyasin, K. (2007). 'Studi Antropologi Masyarakat dan Budaya Keerom (An Anthropology Study on People and Culture in Keerom - Papua),' Fakultas Sastra UNIPA kerjasama dengan BAPPEDA Kabupaten Keerom (A collaboration academic project between the local government of Keerom and State University of Papua).

Yamaguchi, K. (1990). "Homophily and Social Distance in the Choice of Multiple Friends," Journal of the American Statistical Association, 85, 356-366

Zapalska, A. M. \& Edwards, W. (2001). "Chinese Entrepreneurship in a Cultural and Economic Perspective," Journal of Small Business Management,39(3), 286-292. 